\title{
EREBEA
}

Revista de Humanidades y Ciencias Sociales

Núm. 10 (2020), pp. 129-146

ISSN: 0214-0691

http://dx.doi.org/10.33776/erebea.v10i0.4956

\section{HOW SOCIAL CONNECTION HELPS PROMOTE MENTAL HEALTH AND POSITIVE HUMAN DEVELOPMENT IN COLLEGE STUDENTS IN Portugal? - Data from the national HBSC/ JUnP}

\author{
Marta Reis ${ }^{1,2}$ \\ Lúcia Ramiro ${ }^{1,2}$ \\ Gina Tomé ${ }^{1,2}$ \\ Cátia Branquinho ${ }^{1,2}$ \\ Diego Gomez-Baya ${ }^{1,2,3}$ \\ Tania Gaspar ${ }^{1,4}$ \\ Margarida Gaspar de Matos ${ }^{1,2,5}$ \\ ${ }^{1}$ Faculdade de Motricidade Humana \\ Universidade de Lisboa, Portugal \\ ${ }^{2}$ ISAMB/Faculdade de Medicina, Universidade de Lisboa, Portugal \\ ${ }^{3}$ Department of Social, Developmental and Educational Psychology, \\ Universidad de Huelva, Huelva, Spain \\ ${ }^{4}$ Universidade Lusiada de Lisboa, Portugal \\ ${ }^{5}$ ISPA, APPSYci, Portugal
}

ABSTRACT

Humans are social animals, and crave feeling supported, valued and connected. Research shows that social connection provides important benefits to mental health and positive human development. The aim of this study was to explore how social connection helps promote mental health and positive human development and report the associations with the PYD construct of connection with different dimensions of mental health (e.g. self-regulation, resilience, anxiety, aggressiveness and worries), life satisfaction and academic performance in a large sample of Portuguese students. The HBSC/JUnP data base comprises a representative sample

\section{RESUMEN}

Los seres humanos son animales sociales y desean sentirse apoyados, valorados y conectados. La investigación muestra que la conexión social proporciona importantes beneficios para la salud mental y el desarrollo humano positivo. El objetivo de este estudio fue explorar cómo la conexión social ayuda a promover la salud mental y el desarrollo humano positivo e examinar las asociaciones con la dimensión de conexión dentro del constructo de desarrollo positivo juvenil con diferentes dimensiones de la salud mental (por ejemplo, autorregulación, resiliencia, ansiedad, agresividad y preocupaciones), satisfacción con la vida y rendimiento académico, en una amplia 
of 2991 college students $(n=2203 ; 73.7 \%$ women) and their age ranged from 18 to 35 years old $(22.43 \pm 3.83)$. Participants' socio-demographic characteristics included sex, age and academic degree; besides participants were inquired about the PYD construct of connection and its subdimensions (family, university, neighbourhood, peers), mental health (namely self-regulation, resilience, anxiety, aggressiveness, worries), life satisfaction and academic performance. Results showed that all variables had mostly significantly correlational associations. Specifically, the linear regression model evidenced that the promotion of self-regulation and resilience, along with the reduction of anxiety and worries, can be relevant for improving social connections (PYD Connection).

KeYwords

Positive development; Connection; Self-regulation; Mental health; Academic performance; College students; Portugal.

Fecha de recepción: 24 de septiembre de 2020 Fecha de aceptación: 26 de octubre de 2020 muestra de estudiantes portugueses. La base de datos HBSC / JUnP comprende una muestra representativa de 2991 estudiantes universitarios $(n=2203 ; 73,7 \%$ mujeres) y con edades entre los 18 y los 35 años $(22,43 \pm 3,83)$. Las características sociodemográficas de los participantes estudiadas fueron sexo, edad y grado académico; además, se preguntó a los participantes sobre el constructo de desarrollo positivo juvenil de conexión y sus diferentes subdimensiones (familia, universidad, barrio, e iguales), salud mental (es concreto, autorregulación, resiliencia, ansiedad, agresividad, y preocupaciones), satisfacción con la vida y rendimiento académico. Los resultados mostraron que todas las variables tenían asociaciones correlacionales mayoritariamente significativas. Específicamente, el modelo de regresión lineal evidenció que la promoción de la autorregulación y la resiliencia, junto con la reducción de la ansiedad y las preocupaciones, pueden ser relevantes para mejorar las conexiones sociales (dentro del desarrollo positivo juvenil).

\section{Palabras Clave}

Desarrollo positivo; Conexión; Autorregulación; Salud mental; Rendimiento académico; Estudiantes universitarios; Portugal.

\section{FUNDING}

Foundation for Science and Technology (FCT) (Grants: Marta Reis -SFRH/ $\mathrm{BPD} / 110905 / 2015)$

\section{ACKNOWLEDGEMENTS}

A special thanks to Aventura Social team and to all the universities, students, teachers and experts who participated in this study. To the HBSC/ WHO network (www.hbsc.org) and the Positive Youth Development cross-national project (https://www.uib.no/en/rg/sipa/pydcrossnational) whose surveys was partially used for this purpose. 


\section{INTRODUCTION}

Humans are social animals, and crave feeling supported, valued and connected. Research shows that social connection provides important benefits to mental health and positive human development (Griffin, 2010; Holt-Lunstad, Smith, \& Layton, 2010; Holt-Lunstad, Robles, \& Sbarra, 2017).

Stress may be related to a number of worries (Williams, 2013). However, social connection can help protect people from the harmful effects of stress. When dealing with a stressful situation, people are less likely to report stress-related health problems (for example) when they feel they have support from others (Griffin, 2010; Holt-Lunstad, Smith, \& Layton, 2010; Holt-Lunstad, Robles, \& Sbarra, 2017; MCIntyre, Worsley, Corcoran, Woods, \& Benatll, 2018).

According to those studies, people who are more socially connected to family, friends, or their community are happier, physically healthier and live longer, with fewer mental health problems than people who are less well connected (Griffin, 2010; Holt-Lunstad, Robles, \& Sbarra, 2017).

During childhood and adolescence, we learn how to engage with others from our parents, families and guardians. We mimic behaviour and emotions of those around us, and this early socialisation shapes how we understand and model relationship-forming behaviour throughout life (Barber, \& Olsen, 1997; Fowler, \& Christakis, 2008, Rose, \& Rudolph, 2006).

Although families, parents and caregivers are central to our well-being, during adolescence friends and peers become more significant as young people become more independent and start to build their own social networks. As a result, toxic relationships and negative experiences, such as bullying or social isolation, can be more relevant and have serious impact on young people's mental health (Barber, \& Olsen, 1997; Fowler, \& Christakis, 2008). Schools, teacher-student relationship, and positive support from organisations such as youth clubs can act as a buffer and help protect young people with these negative experiences (Griffin, 2010) as well as help young people develop what the theory about health and well-being assets advocates (Benson, 2007; Benson, Scales, Hamilton, Sesma, 2006; KiaKeating, Dowdy, Morgan, \& Noam, 2010).

Although schools and universities act as a buffer and help protect and promote positive development during this transition stage, new challenges emerge that give joy to discovering new social connections, including the construction 
of academic/professional and family life. However, it is also a time when the main risks of loneliness and isolation, including relationship breakdowns, can significantly impact a poor balance between academic and family life, and the difficulty of managing a life without positive support/ connection, which is fundamental for maintaining a positive development and an active participation of young people in the community (Griffin, 2010; Holt-Lunstad, et al., 2010; Holt-Lunstad, et al, 2017).

The feeling of failure, of incapacity in the face of challenges, obstacles and opportunities may have to do with the lack of assets (internal and / or external), which consequently and indirectly will cause behavioral problems (Scales, Roehlkepartain, \& Fraher, 2012, Small \& Memmo, 2004). As a result, the social connections we maintain in the transition to adulthood are more important to our mental health than we sometimes realize. Those who have more stables connections with family, friends, colleagues and university have been found to be happier, healthier and more satisfied with life. In this stage, the expression Positive Youth Development (PYD) has been used as a unifying philosophy characterized by a positive asset-building orientation (Hamilton, 1999; Simóes, Matos, \& Morgan, 2015; Whitlock \& Hamilton, 2001).

Another important factor to emphasize in positive development of social connections is that they must be developed offline. While online and mobile technologies can provide a means of connecting and can increase the sense of belonging - therefore having a positive impact on social connections - research suggests that this cannot replace offline relationships. It is the neurochemical response that occurs during face-to-face interactions that contributes to wellbeing (Griffin, 2010; MCIntyre, Worsley, Corcoran, Woods, \& Benatll, 2018).

While the social connections impact on mental health, it is important to remember that mental health can impact on how people connect with others and how they develop their relationships. Mental health problems such as anxiety, aggression and depression can influence whether someone feels able to interact and connect to others (Bayram \& Bilgel, 2008; Reis, Gomez-Baya, Ramiro, \& Matos, 2020).

This means that developing connections and socializing in traditional ways can be challenging for some young people. And according to recent studies the percentage of college students with mental health problems has been increasing dramatically (Nogueira, 2016; Reis, Ramiro, Gomez-Baya, \& Matos, 2018; Schleider, Abel, \& Weisz, 2015).

Therefore, support systems, positive social connections, self-esteem, selfregulation and resilience level play an important role in a process of adaptation and coping with the negative influence of early-period negative or traumatic experiences in college students. Considered as a protective factor in terms of negative or traumatic experiences, self-regulation is the ability to monitor and 
manage emotions, thoughts, and behaviors in ways that are acceptable and produce positive results such as well-being, healthy relationships, and learning. It is how we deal with stressors that lays the foundation for all other activity. Developing this ability requires self-awareness, emotional intelligence, efficient filtering of sensory stimulation, coping effectively with stress, relating well to others, and sustaining focus (Gomez-Baya, Mendoza, Paino \& Matos, 2017).

More recently self-regulation has been pinpointed as an important pathway to positive youth development (Matos, Santos, \& Reis, 2017), since it may help prevent adolescents from engaging in risk behaviors (Simôes et al., 2015). High levels of self-regulation are associated with positive behavior, including prosocial behavior and academic achievement, while low levels are related to more externalizing and internalizing problem behavior in adolescence (Matos et al., 2008; Matos, Gaspar, Cruz, \& Neves, 2013). Thus, self-regulation and resilience are associated structures in that self-regulation and resilience help reduce the effects of negative life events with its features of controlling stress and helping an individual cope with stressful situations rather than avoiding them. Recently, Matos, Santos, Reis and Marques (2018) concluded that the promotion of positive youth and self-regulation may be relevant for fostering healthy life-style behaviors in Portuguese youth. In the study conducted by Simões and collaborators (2015), self-regulation was found to be a resilience factor in buffering youth from negative influence of peer deviance and for preventing the development of antisocial behaviors.

According to the body of research on positive development of young people, the approaches on connection dimension can help young people to develop capacities for intentional self-regulation and protectors from engaging in risk behaviours, such as substance use and violence (Bonell et al., 2016) as well as helping young people to promote improved self-care, greater academic achievement, higher quality in interpersonal relationships and overall improvements in well-being (Gomez-Baya, Tomé, Reis, \& Matos, 2020, Maslow \& Chung, 2014).

The present study was carried out with university students, in different regions of Portugal, in order to allow for a representative sample of Portuguese youth in terms of healthy lifestyle behaviors. For the purpose of the present study, in order to understand how social connection helps promote mental health and positive human development we studied a) the difference between genders and academic degree by the connection dimension of the PYD and its subdimensions (family, university, neighbourhood, peers), self-regulation, resilience, anxiety, aggression, worries, life satisfaction and academic performance; b) the relationship between the different variables under study ; and c) the association of the PYD Connection dimension in mental health (through variables like self-regulation, resilience, anxiety, aggressiveness and worries), life satisfaction and academic performance in Portuguese college students. 


\section{Methods}

\section{STUDY DESIGN, PARTICIPANTS AND PROCEDURES}

The national HBSC/JUnP study is an extension of two investigations conducted by the Social Adventure team - HBSC (Health Behaviour in school aged children; http://aventurasocial.com/verartigo.php?article_id=238) and HBSC/SSREU (Sexual and Reproductive Health of university students; http:// aventurasocial.com/verartigo.php?article_id=98). The HBSC/JUnP followed all the rules for research outlined in 2008 by the World Medical Association Declaration of Helsinki, and was approved by the Ethics Commission of the Medicine Academic Center of Lisbon of the Faculty of Medicine, University of Lisbon.

The HBSC/JUnP data base comprises a representative sample of 2991 college students ( $\mathrm{n}=2203 ; 73.7 \%$ women), with ages ranging from 18 to 35 years old $(22.43 \pm 3.83)$. As for academic degree, $62 \%$ were undergraduate ( $n=1853), 29 \%$ were master degree students $(\mathrm{n}=868)$ and $9 \%$ were attending other academic degrees $(\mathrm{n}=270)$.

Data collection was performed using an online cross-sectional survey administered to the Portuguese college students in the Limesurvey platform. The students could access the survey with any electronic device that was capable of accessing their email. The survey began with a brief description of the study itself, followed by a detailed informed consent form that explained participants' rights, perceived risks and benefits of participation, and the measures taken by the researchers to keep their personal information confidential. The students could access the survey only after they agreed to this informed consent. It took a participant around 25/30 min to fill out the survey.

\section{Measures}

For the purpose of this study the following variables were selected:

a) Participants' sociodemographic characteristics, which included sex, age and academic degree.

b) PYD Connection dimension, which was measured by eight issues: (1) you havepositive conversations with your parents regularly, (2), you feel useful and important in your family, (3)_you are highly encouraged at your university, (4) your teachers encourage you to be the best you can possibly be, (5) adults in your neighbourhood make you feel important, (6) adults in your neighbourhood hear what you have to say (categorized as strongly disagree, disagree, not sure, agree, and totally agree) (7) you feel that your friends are good friends, and (8) your friends care about you (categorized as never true, rarely true, sometimes are true, often true, and always true). Regarding the average PYD Connection dimension, the results obtained 
can vary between 8 and 40 points, with the highest value as an indicator of strong connection. As for the 4 subdimensions (family - the sum of items 1 and 2; university - the sum of items 3 and 4; neighbourhood - the sum of items 5 and 6; and peers - the sum of items 7 and 8), the results obtained can vary between 2 and 10 points, with higher values indicating a strong connection in a specific subdimension.

As for life satisfaction, college students were asked how they felt about their life (categorized between not at all satisfied to very satisfied).

Academic performance was measured by questioning them on how they perceived their academic performance and response options were "poor/ reasonable", "good", and "very good/excellent", which were after dichotomized into "bad" ("poor/reasonable") and "good" ("good" and "very good/excellent").

Mental health was measured by one question about frequency of worries and by four scales: (1) Self-regulation-SR (Dias, Castillo, \& Moilanen, 2014), (2) Resilience-RES (Constantine, Benard, \& Diaz, 1999), (3) Anxiety-STAI-T (Silva, \& Spielberger, 2007), and (4) Buss-Perry aggression (Buss, \& Perry, 1992).

\section{DATA ANALYSIS}

Descriptive analysis (means, standard deviation and percentage) were used to characterize the sample. All data were tested for normality prior to any analyses using Kolmogorov-Smirnov tests, as well as Levene's test for the homogeneity of the variance. Psychometric analyses were also performed through an analysis of the coefficient of internal consistency (Cronbach's alpha). Pearson correlation and linear regression were performed to evaluate significant differences in the analyzed variables among the total group of participants. All statistical analyses were completed using the SPSS 24.0 (Statistical Package for Social Sciences) and the significance level was set at $\mathrm{p}<0.05$.

\section{REsults}

Table 1 shows the characteristics of the sample for the variables under study. The results obtained in the PYD Connection dimension $(M=28.01 ; S D=4.85)$, and its subdimensions - PYD Family Connection $(M=7.33$; $S D=1.81)$; PYD University Connection $(M=6.97 ; S D=1.72)$; PYD Neighbourhood Connection $(M=5.81 ; S D=1.92)$ and PYD Peers Connection $(M=7.89 ; S D=1.54)$ show that young Portuguese university students have good and above average values for the Connection dimension and its subdimensions, with the exception of the PYD Neighbourhood Connection subdimension, which presents values slightly below the average.

Regarding mental health issues, it was observed that more than a third of young university students have worries several times a week (36.4\%). The results obtained in the scales that evaluated Self-regulation, Resilience, Anxiety and 
Aggressiveness showed that young Portuguese university students have median values with regard to self-regulation $(M=143.94 ; S D=16.68)$ and resilience $(M$ $=55.49 ; S D=8.09)$, but they also have median values for anxiety $(M=44.58$; $S D=9.28)$ and for aggressiveness $(M=57.14 ; S D=16.62)$.

Regarding satisfaction with life, young people presented good results $(M=$ 6.99; $S D=1.91$ ), but in the questions that assessed academic performance, more than a quarter of young people reported having a poor or reasonable academic performance $(27.9 \%)$.

Differences between gender and academic degree and the variables under study of the Portuguese university students are shown in table 2.

Statistically significant differences were found between gender for the PYD subdimension Family Connection $(F(1,2989)=6.125, p=.013)$, the PYD subdimension Peers Connection $(F(1,2989)=4.027, p=.045)$, Self-regulation - total score $(F(1,2989)=46.716, p=.000)$, Resilience $(F(1,2989)=30.950$, $p=.000)$, Worries $(\mathrm{X} 2(4)=44.605 ; p<.001)$ and Academic performance $(\mathrm{X} 2(2)$ $=9.418 ; p<.001)$.

Women showed a positive and significantly larger Family and Peers connection $(M=7.37, S D=1.83 ; M=7.93, S D=1.52$, respectively $)$, more Self-regulation $(M=145.33, S D=18.73)$ and more Resilience $(M=55.98, S D$ $=8.06$ ) when compared with men. But they also reported having worries more often (several times a day $-10 \%$ and several times a week 37.6\%) than men. With regard to academic performance, women considered their performance to be good $(56.8 \%)$ while men more often reported having very good / excellent performance (19.8\%).

Finally, statistically significant differences were found between academic degrees for the PYD subdimension Family Connection $(F(2,2988)=3.305, p$ $=.037)$, the PYD subdimension University Connection $(F(2,2988)=3.320$, $p=.036)$, the PYD subdimension Neighbourhood Connection $(F(2,2988)=$ $13.768, p=.000)$, Self-regulation - total score $(F(2,2988)=12.612, p=.000)$, Resilience $(F(2,2988)=3.604, p=.027)$, Anxiety-trait $($ STAI-T $)(F(2,2988)=$ $4.376, p=.013)$, Worries $(\chi 2(4)=24.854 ; p<.010)$ and Academic performance $(\chi 2(2)=155.829 ; p<.001)$.

The Post-hoc comparisons by the Games-Howell method for the PYD subdimension University Connection and the PYD subdimension Neighbourhood Connection and Tukey method for other variables indicated that undergraduates reported having less Family and Neighbourhood connection $(M=7.27, S D=1.84, M=5.68, S D=1.91$, respectively $)$, less Self-regulation total $(M=142.63, S D=18.17)$, less Resilience $(M=55.24, S D=8.09)$, more University Connection $(M=7.02, S D=1.64)$ and more Anxiety $(M=48.97$, $S D=9.05)$. Regarding Worries and Academic performance, undergraduates 
Total Group (N=2991)

\begin{tabular}{|c|c|c|c|c|}
\hline \multicolumn{5}{|c|}{ Socio-demographic characteristics } \\
\hline Age (years) $(\mathrm{M} \pm \mathrm{SD})$ & & $22.43 \pm 3.83$ & & \\
\hline \multicolumn{5}{|l|}{ Gender (N; \%) } \\
\hline Male & & $788 ; 26.3$ & & \\
\hline Female & & $2203 ; 73.7$ & & \\
\hline \multicolumn{5}{|l|}{ Academic degree $(\mathrm{N} ; \%)$} \\
\hline Undergraduate degree & & $1853 ; 62.0$ & & \\
\hline Master degree & & $868 ; 29.0$ & & \\
\hline Other academic degrees & & $270 ; 9.0$ & & \\
\hline \multicolumn{2}{|c|}{$\begin{array}{l}\text { PYD-CONNECTION and its subdimensions } \\
(\mathrm{M} \pm \mathrm{SD})\end{array}$} & & Min. & Max. \\
\hline \multicolumn{2}{|c|}{ PYD - Connection dimension - Total score } & $\begin{array}{r}28.014 \pm \\
4.85\end{array}$ & 8 & 40 \\
\hline \multicolumn{2}{|c|}{ PYD - Family Connection - subdimension } & $7.33 \pm 1.81$ & 2 & 10 \\
\hline \multicolumn{2}{|c|}{ PYD - University Connection - subdimension } & $6.97 \pm 1.72$ & 2 & 10 \\
\hline \multicolumn{2}{|c|}{ PYD- Neighbourhood Connection - subdimension } & $5.81 \pm 1.92$ & 2 & 10 \\
\hline \multicolumn{2}{|c|}{ PYD - Peers Connection - subdimension } & $7.89 \pm 1.54$ & 2 & 10 \\
\hline \multicolumn{2}{|l|}{ Psychosocial variables $(\mathrm{M} \pm \mathrm{SD})$} & & Min. & Max. \\
\hline \multicolumn{2}{|l|}{ Self-regulation - Total Score } & $\begin{array}{r}143.94 \pm \\
18.68 \\
\end{array}$ & 78 & 203 \\
\hline Resilience- Total Score & & $55.49 \pm 8.09$ & 21 & 72 \\
\hline \multicolumn{2}{|l|}{ STAI - ${ }^{* *}$-Total Score } & $44.58 \pm 9.28$ & 23 & 74 \\
\hline \multicolumn{2}{|c|}{ Buss-Perry aggression - Total Score } & $\begin{array}{r}57.14 \pm \\
16.623 \\
\end{array}$ & 25 & 125 \\
\hline \multicolumn{2}{|l|}{ Life Satisfaction $(\mathrm{M} \pm \mathrm{SD})$} & & Min. & Max. \\
\hline Life Satisfaction & & $6.99 \pm 1.91$ & 0 & 10 \\
\hline \multicolumn{5}{|l|}{ Worries - frequency $(\mathrm{N} ; \%)$} \\
\hline Several times a day & & $264 ; 8.8$ & & \\
\hline Almost every day & & $564 ; 18.9$ & & \\
\hline Several times a week & & $1090 ; 36.4$ & & \\
\hline Several times a month & & $827 ; 27.6$ & & \\
\hline Almost never & & $246 ; 8.2$ & & \\
\hline \multicolumn{5}{|l|}{ Academic Performance (N; \%) } \\
\hline Poor/Reasonable & & $833 ; 27.9$ & & \\
\hline Good & & $1654 ; 55.3$ & & \\
\hline Very good/ Excellent & & $504 ; 16.9$ & & \\
\hline
\end{tabular}

Table 1- Descriptive of the variables under study ( $\mathrm{n}=2991)$

* Positive Youth Development - Connection dimension; ${ }^{* *}$ STAI-T: State-Trait Anxiety Inventory, Trait 


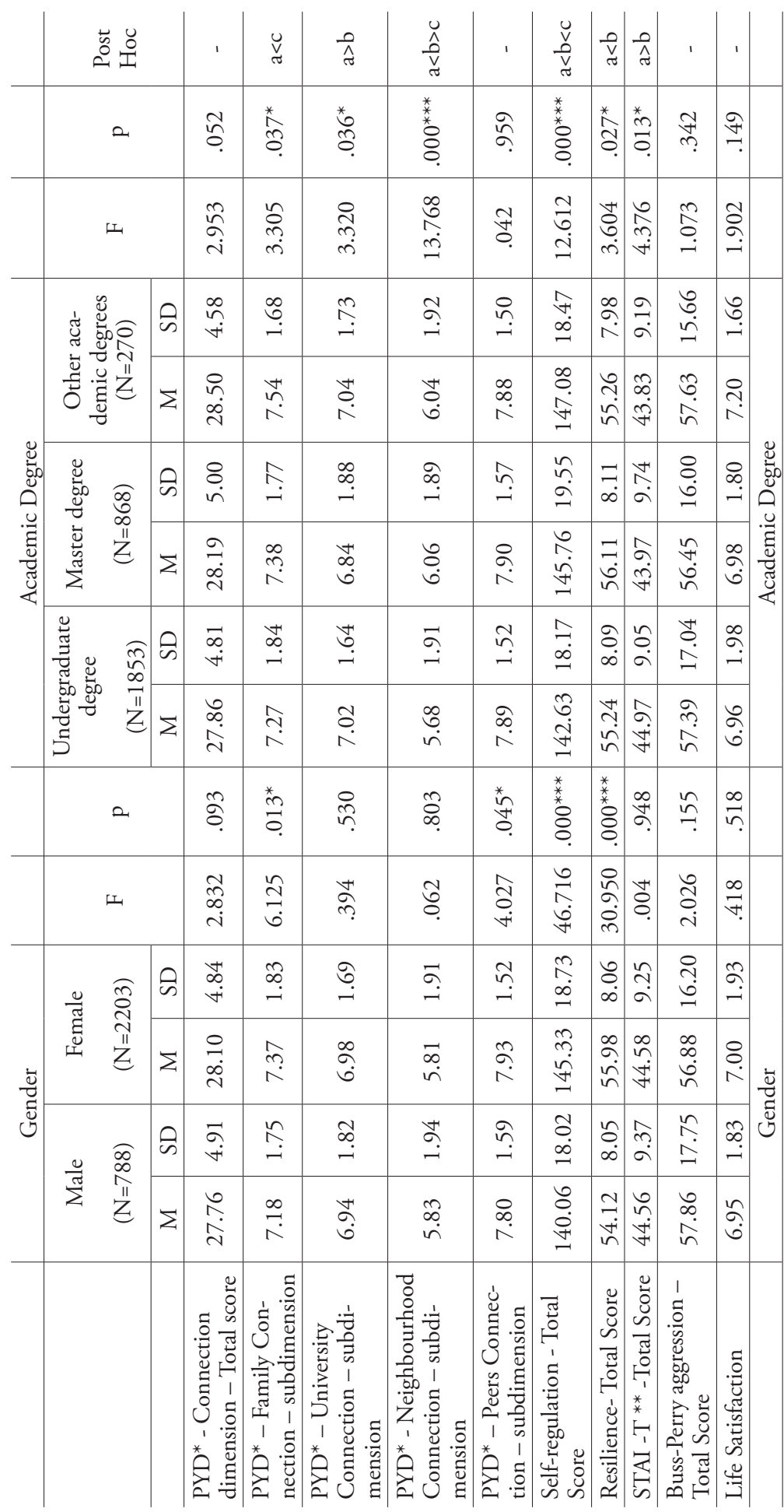




\begin{tabular}{|c|c|c|c|c|c|c|c|c|c|c|c|c|}
\hline 2 & & 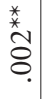 & & & & & & 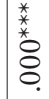 & & & & సે \\
\hline$\stackrel{N}{x}$ & & 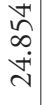 & & & & & & 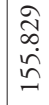 & & & & $\frac{\tilde{D}}{\overrightarrow{0}}$ \\
\hline 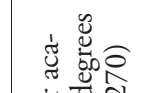 & $0^{0}$ & & $\stackrel{\Downarrow}{\sim}$ & $\approx$ & $\hat{\mathrm{i}}$ & $\begin{array}{l}\text { i. } \\
\text { ते }\end{array}$ & $\stackrel{t}{0}$ & & $\triangleq$ & $\stackrel{\infty}{\mathbb{f}^{+}}$ & $\vec{\infty}$ & 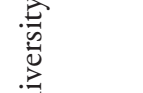 \\
\hline 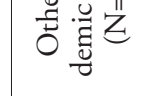 & Z & & ิㅗ & $\widetilde{\sigma}$ & $N$ & $\infty$ & $\stackrel{\infty}{\sim}$ & & 나 & 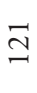 & $\stackrel{m}{0}$ & U్ \\
\hline 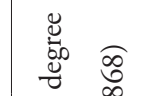 & $0^{\circ}$ & & $\stackrel{\bullet}{r}$ & ?े & $\stackrel{q}{\text { mे }}$ & $\stackrel{\Downarrow}{\grave{\lambda}}$ & $\stackrel{\infty}{\sim}$ & & $\ddot{\sim}$ & $\stackrel{\infty}{i}$ & $\overrightarrow{\mathrm{N}}$ & 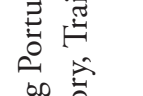 \\
\hline 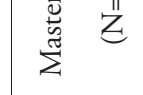 & Z & & రి & $\stackrel{๑}{I}$ & 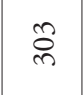 & $\tilde{n}$ & $\infty$ & & ¿ & $\stackrel{2}{\forall}$ & 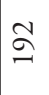 & 怘 \\
\hline 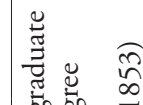 & $a^{\circ}$ & & $\stackrel{v}{a}$ & $\stackrel{0}{N}$ & $\begin{array}{l}0 \\
\infty \\
\infty\end{array}$ & $\overrightarrow{\mathrm{d}}$ & $\vec{\infty}$ & & $\hat{\bar{m}}$ & $n$ & $\stackrel{?}{=}$ & 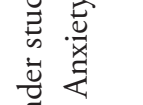 \\
\hline 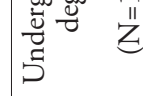 & Z & & $\stackrel{\infty}{\simeq}$ & ñ & $\stackrel{n}{n}$ & $\stackrel{+}{+\infty}$ & $\stackrel{0}{n}$ & & in & in & ळे & 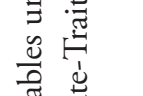 \\
\hline 2 & & $\begin{array}{l}* \\
* \\
0 \\
8 \\
0 \\
\end{array}$ & & & & & & 类 & & & & 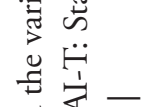 \\
\hline$\sqrt{x}$ & & $\begin{array}{l}n \\
0 \\
b \\
\dot{+} \\
\dot{f}\end{array}$ & & & & & & $\stackrel{\infty}{\underset{\forall}{\sigma}}$ & & & & 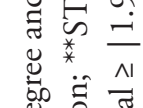 \\
\hline స్ & $0^{\circ}$ & & 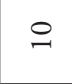 & $\begin{array}{l}2 \\
\infty \\
-\end{array}$ & 官 & તิ & 它 & & $\stackrel{\Downarrow}{\stackrel{\star}{\nu}}$ & 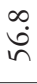 & $\begin{array}{l}\infty \\
\ddot{n}\end{array}$ & 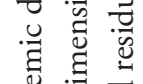 \\
\hline 㱏 & Z & & તิ & $\frac{6}{\nabla}$ & $\underset{\infty}{\infty}$ & $\stackrel{\star n}{n}$ & $\stackrel{n}{ \pm}$ & & ठ্ & $\stackrel{\sqrt{n}}{\approx}$ & 文 & 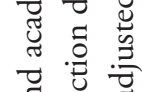 \\
\hline$\infty$ & $\partial^{\circ}$ & & $\stackrel{b}{i}$ & $\begin{array}{l}\infty \\
\infty \\
-\end{array}$ & $\stackrel{\sim}{m}$ & 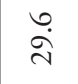 & $\begin{array}{l}\infty \\
\stackrel{I}{I}\end{array}$ & & $\overrightarrow{\grave{\lambda}}$ & $\stackrel{\rightleftarrows}{\varpi}$ & $\stackrel{\infty}{\infty}$ & 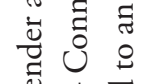 \\
\hline z & Z & & $\mathbb{F}$ & $\stackrel{\infty}{+}$ & స్ర & $\stackrel{\sim}{\sim}$ & 음 & & নิ & $\stackrel{\text { ôt }}{\text { के }}$ & 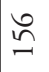 & 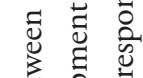 \\
\hline & & 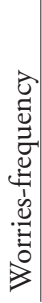 & 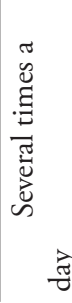 & 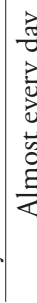 & 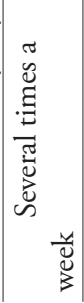 & 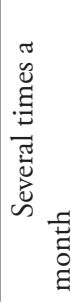 & 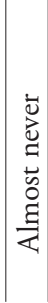 & 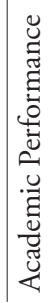 & 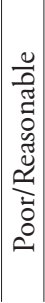 & $\begin{array}{l}\text { D } \\
\circ \\
ن\end{array}$ & 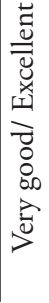 & 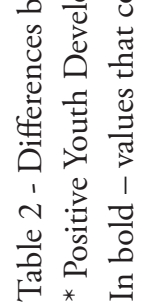 \\
\hline
\end{tabular}


referred more frequently having worries several times a week (38.6\%) and poor/ reasonable Academic performance (31.7\%).

The correlations between the PYD Connection dimension (total score) and its subdimensions with the Mental health issues and the Academic performance are shown in Table 3. As for the PYD Connection dimension - total score (and its subdimensions), Self-regulation, Resilience and Academic performance, it was mainly observed a significant positive linear association, and a significant negative linear association with Anxiety (STAI-T), Aggressiveness (Buss-Perry aggression) and Worries.

Table 4 shows the results of the linear regression analysis for PYD Connection (total score) and variables under study. A model was achieved for PYD Connection (total score) $[F(7,2983)=184.975, p<0.001, \mathrm{R} 2=.550]$. With the exception of Life satisfaction and Aggressiveness, all variables under study (Self-regulation, Resilience, Anxiety-trait, Worries and Academic performance) had a statistically significant association: young people who had presented a higher score in selfregulation and resilience and a lower score in anxiety and worries were more likely to have higher score in PYD connection.

\section{Discussion}

The aim of this paper was to understand how social connection helps promote mental health and positive human development, studied through the analysis of the correlations between the PYD Connection dimension and its subdimensions, a composite of risk and protective factors for mental health (self-regulation, resilience, anxiety and aggressiveness), satisfaction with life, worries and academic performance. A brief analysis of the results showed that most of the variables in this study have significantly correlational associations. Thus, it seems that positive youth development, resilience, self-regulation and academic performance are connected, interacting in a positive correlational way, whereas anxiety, aggressiveness and worries interact in a negative direction. These results are in line with other studies with adolescents (Matos et al., 2008; Matos, Gaspar, Cruz, \& Neves, 2013; Matos, Santos, \& Reis, 2017) and with the Mental Health Foundation's belief that we urgently need a greater focus on the quality of social connections (Griffin, 2010). It is necessary to understand to what extent relationships are fundamental to health and well-being as we cannot flourish as individuals and communities without them. In fact, they are as vital as betterestablished lifestyle factors, such as eating well, exercising more and giving up on smoking.

Specifically, when analyzing the individual impact of the studied variables with positive youth development connection a significant association with a higher value of explained variance was obtained (30\%). The aggressiveness was no longer significant and the other variables related with mental health (resilience, 


\begin{tabular}{|c|c|c|c|c|c|c|c|c|c|c|c|c|c|}
\hline I & ' & 1 & 1 & & 1 & . & 1 & 1 & 1 & . & , & & \\
\hline 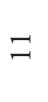 & 1 & ' & ' & ' & ' & 1 & 1 & ' & 1 & 1 & ' & $\stackrel{\substack{* \\
\stackrel{*}{*}}}{\stackrel{m}{1}}$ & \\
\hline$\stackrel{ }{ }$ & ' & ' & ' & ' & ' & 1 & ' & ' & ' & 1 & $\tilde{\delta}$ & $\begin{array}{l}\text { ¿̦ } \\
\text { o. }\end{array}$ & \\
\hline$a$ & ' & 1 & 1 & & 1 & 1 & 1 & ' & 1 & $\vec{a}$ & 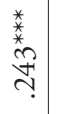 & : & \\
\hline$\infty$ & ' & ' & ' & & ' & 1 & 1 & ' & 苦 & \begin{tabular}{l}
$\stackrel{*}{*}_{+}^{+}$ \\
\multirow{i}{*}{} \\
$i$
\end{tabular} & 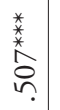 & $\stackrel{\substack{* \\
\stackrel{*}{*}}}{\stackrel{\text { ț }}{\stackrel{1}{*}}}$ & \\
\hline$\wedge$ & ' & I & ' & 1 & ' & 1 & ' & 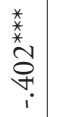 & $\begin{array}{l}\stackrel{*}{*} \\
\stackrel{*}{*} \\
\stackrel{i}{i}\end{array}$ & તิ & \begin{tabular}{c}
$\stackrel{*}{*}$ \\
\multirow{*}{*}{} \\
$\stackrel{0}{\Xi}$ \\
$\stackrel{i}{i}$
\end{tabular} & $\begin{array}{l}\stackrel{*}{*} \\
\stackrel{*}{*} \\
\stackrel{0}{1}\end{array}$ & تี \\
\hline ○ & ' & 1 & ' & ' & 1 & 1 & 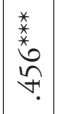 & 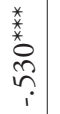 & 芰 & గి & 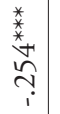 & 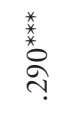 & 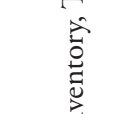 \\
\hline$n$ & ' & ' & ' & & 1 & 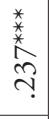 & 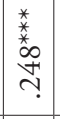 & 苾 & $\begin{array}{c}\stackrel{*}{*} \\
\stackrel{*}{*} \\
\stackrel{*}{*} \\
i\end{array}$ & $\stackrel{8}{8}$ & $\stackrel{*}{*}$ & $\stackrel{*}{*} \tilde{\sigma}$ & 离 \\
\hline$\checkmark$ & ' & 1 & 1 & & 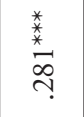 & 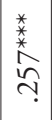 & 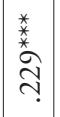 & $\begin{array}{c}\stackrel{*}{*} \\
\stackrel{*}{*} \\
\stackrel{\overbrace{}}{2}\end{array}$ & ${ }_{i}^{*}$ & \begin{tabular}{l} 
*o \\
\multirow{2}{0}{} \\
0
\end{tabular} & 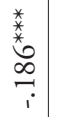 & 苦 & 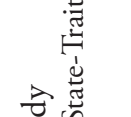 \\
\hline$n$ & ' & ' & 1 & 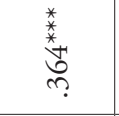 & $\stackrel{\text { * }}{\stackrel{*}{*}}$ & 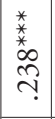 & 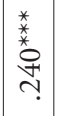 & 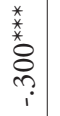 & $\begin{array}{l}\stackrel{*}{*} \\
\stackrel{*}{0} \\
? \\
:\end{array}$ & $\stackrel{m}{8}$ & 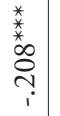 & 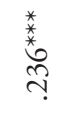 & 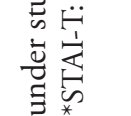 \\
\hline$N$ & ' & ' & 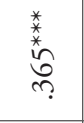 & 菊 & ণ़ & \begin{tabular}{|l}
$*$ \\
$*$ \\
$*$ \\
$m$ \\
$m$
\end{tabular} & 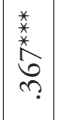 & 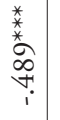 & $\begin{array}{l}\stackrel{*}{*} \\
\stackrel{*}{*} \\
\stackrel{7}{*}\end{array}$ & ڤે & 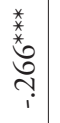 & 苦 & 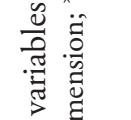 \\
\hline- & ' & 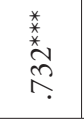 & 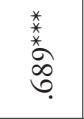 & 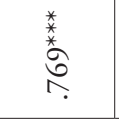 & 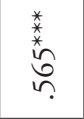 & 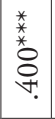 & \begin{tabular}{l}
$*$ \\
$*$ \\
$*$ \\
\multirow{2}{*}{} \\
\end{tabular} & $\begin{array}{c}\stackrel{*}{*} \\
\stackrel{*}{*} \\
\stackrel{*}{*}\end{array}$ & $\begin{array}{l}\stackrel{*}{*} \\
\stackrel{*}{*} \\
\stackrel{+}{ \pm} \\
i !\end{array}$ & है & $\begin{array}{l}\stackrel{*}{*} \\
* \\
* \\
0 \\
0 \\
i \\
1\end{array}$ & 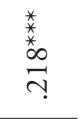 & 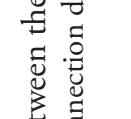 \\
\hline & 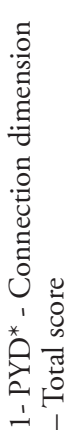 & 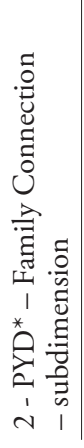 & 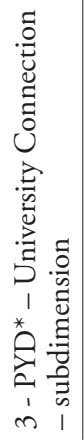 & 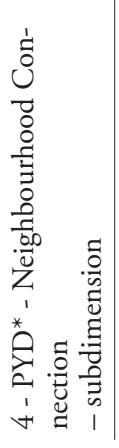 & 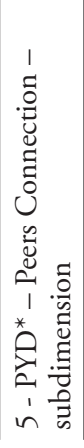 & 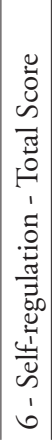 & 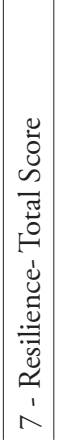 & 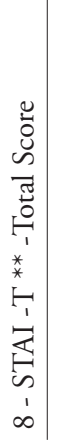 & 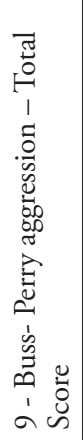 & 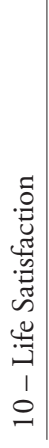 & 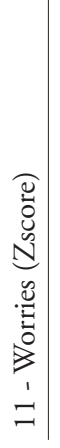 & 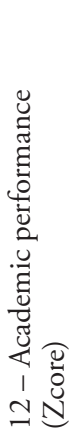 & 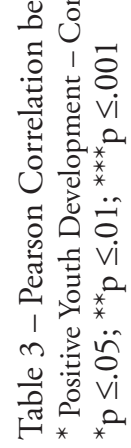 \\
\hline
\end{tabular}




\begin{tabular}{l|l|r|r|r} 
& & $\beta$ & $\mathrm{t}$ & $\mathrm{p}$ \\
\hline \multirow{4}{*}{$\begin{array}{c}\text { PYD* - Connection } \\
\text { dimension - Total score }\end{array}$} & Self-regulation - Total Score & .121 & 6.274 & .000 \\
\cline { 2 - 5 } & Resilience- Total Score & .208 & 11.842 & .000 \\
\cline { 2 - 5 } & STAI -T ${ }^{* *}$-Total Score & -.282 & -13.241 & .000 \\
\cline { 2 - 5 } & Buss-Perry aggression - Total Score & .030 & 1.844 & .065 \\
\cline { 2 - 5 } & Life Satisfaction & .014 & .938 & .348 \\
\cline { 2 - 5 } & Worries (Zscore) & -.093 & -5.167 & .000 \\
\cline { 2 - 5 } & Academic performance (Zcore) & .050 & 3.060 & .002 \\
\hline $\begin{array}{l}\text { Variance explained (\%) } \\
-30 \%\end{array}$ & $\begin{array}{l}\mathrm{R}^{2}=.550 \mid \mathrm{F}(7,2983)=184.975 \\
\mathrm{p}=.000\end{array}$ & & & \\
& & & &
\end{tabular}

Table 4 - Linear regression between the variables under study

* Positive Youth Development - Connection dimension; ${ }^{* *}$ STAI-T: State-Trait Anxiety Inventory, Trait

${ }^{*} \mathrm{p} \leq .05 ;{ }^{* *} \mathrm{p} \leq .01 ;{ }^{* * *} \mathrm{p} \leq .001$

Analyses were adjusted for gender

self-regulation and anxiety), worries and academic performance had a significant association with the PYD Connection dimension (total score). These findings are in accordance with literature, which pointed out the relevance of strengthapproaches (as the PYD) and psychosocial factors for health outcomes (Benson, 2007; Small \& Memmo, 2004). Such results suggest a dynamic interdependence between all the variables in the study, PYD Connection, self-regulation, resilience, anxiety, worries and academic performance. More specifically, the linear regression model puts in evidence that the promotion of self-regulation, resilience and academic performance along with the reduction of anxiety and worries can have a relevant impact in improving social connections (PYD Connection).

\section{Practical Implications}

In addition, these findings reinforce the need to continue to study positive indicators, and to strengthen internal and external developmental assets (Small \& Memmo, 2004). The present results are also in line with recent recommendations of the Mental Health Foundation, namely the need to include social connection with psychosocial and health factors (Griffin, 2010).

Additionally, the evidence of these findings may suggest that to increase the mental health and well-being it is also needed to strengthen positive connections with different environments, namely family, peers, school/university and neighbourhood.

It is aimed to increase knowledge on these areas because it could help promote healthy development in a more effective way. Furthermore, identifying positive indicators, such as positive youth development and the importance of different 
social connections, can offer useful suggestions to health professionals, educators and policy-makers on how to plan effective interventions and policies.

This paper suggests specific recommendations regarding education government policies targeting young adults (university and college students) in order to promote their well-being, general performance, sense of competence, confidence, connection and achievement, thus increasing their mental-health, active social participation and thriving. University students are often very focused on academic performance and academic grades, but things are not totally distinct. University students often lack adequate support regarding this issue.

\section{Limitations AND STRENGTHS}

The present results need to be interpreted keeping in mind that recall bias might be introduced through self-report, and some youths may be underrepresented due to the group's heterogeneity; and that the cross-sectional design of the study precludes inferences concerning causality and thus longitudinal data would be needed.

The present study has numerous strengths, such as including self-reports from a large sample of young people, and using measures that have been shown to be suitable to assess the importance of social connection (family, university, neighbourhood and peers) and how it can influence mental health and academic performance, that are validated for the Portuguese population, and that have been used in an international project -the Health Behaviour in School-aged Children (HBSC/WHO).

\section{REFERENCES}

Barber, B.K., \& Olsen, J.A. (1997). Socialization in context: Connection, regulation, and autonomy in the family, school, and neighborhood, and with peers. Journal of Adolescent Research, 12, 287-315.

Benson, P.L. (2007). Developmental assets: an overview of theory, research and practice. In: Silbereisen RK, Lerner RM, editors. Approaches to Positive Youth Development (pp. 33-58). Thousand Oaks: Sage.

Benson, P.L., Scales, P.C., Hamilton, S.F., Sesma, A. (2006). Positive Youth development: Theory, research and application. In W. Damon, R.M., Lerner (Eds.), Handbook of Child Psychology, (6th ed., pp. 894-941). New York: Wiley.

Bonell, C., Hinds, K., Dickson, K., Thomas, J., Fletcher, A., Murphy, S., Melendez-Torres, G.J., Bonell, C., \& Campbell, R. (2016). What is positive youth development and how might it reduce substance use and violence? A systematic review and synthesis of theoretical literature. BMC Public Health, 16, 135. doi: 10.1186/s12889-016-2817-3 
Buss, A.H., \& Perry, M. (1992). The Aggression Questionnaire. Journal of Personality and Social Psychology, 63, 452-459.

Constantine, N., Benard, B., \& Diaz, M. (1999). Measuring Protective Factors and Resilience Traits in Youth: The Healthy Kids Resilience Assessment, from www.education.ucsb.edu/newvistas/files/append.pdf

Dias, P., Castillo, J.A., \& Moilanen, K. (2014). The Adolescent Self-Regulatory Inventory (ASRI) Adaptation to Portuguese Context. Paidéia, 24(58), 155.163. doi: $10.1590 / 1982-43272458201403$

Fowler, J. \& Christakis, N .A. (2008). Dynamic spread of happiness in a large social network: longitudinal analysis over 20 years in the Framingham Heart Study. BMJ, 337:a2338.

Griffin, J. (2010). The Lonely Society. Mental Health Foundation. Available at: www.mentalhealth.org.uk/sites/default/files/the_lonely_society_report.pdf [Accessed on 17/07/20].

Gomez-Baya, D., Mendoza, R., Paino, S., \& Matos, M. G. (2017). Perceived emotional intelligence as a predictor of depressive symptoms during midadolescence: A two longitudinal study on gender differences. Personality and Individual Differences, 104: 303-312.https://doi.org/10.1016/j.paid.2016.08.022

Gomez-Baya, D., Tomé, G., Reis, M. \& Matos, M.G. (2020). Internal Resources for Resilience and Positive Youth Development in a National Sample in Portugal: A Moderated-mediation Analysis of Self-regulation by Gender. The journal of Genetic Psychology, 181(2-3): 127-149. https://doi.org/10.1080/00 221325.2020.1735986

Hamilton, S.F. (1999). A three-part definition of youth development. Unpublished manuscript, Cornell University College of Human Ecology, Ithaca NY

Holt-Lunstad, J., Smith, T.B. \& Layton, J.B. (2010). Social Relationships and Mortality Risk: A Meta-analytic Review. PLoS Med, 7 (7), http://dx.doi. org/10.1371/journal.pmed.1000316

Holt-Lunstad, J., Robles, T.F., \& Sbarra, D.A. (2017). Advancing social connection as a public health priority in the United States. American Psychologist, 72(6), 517-530, https://doi.org/10.1037/amp0000103

Kia-Keating, M., Dowdy, E-. Morgan, M., \& Noam, G. (2010). Protecting and Promoting: An Integrative Conceptual Model for Healthy Development of Adolescents. Journal of Adolescent Health, 48, 220-228. doi:10.1016/j. jadohealth.2010.08.006

Matos, M. G., Gaspar, T., Cruz, J., \& Neves, A. M. (2013). New highlights about worries, coping, and well-being during childhood and adolescence. Psychology Research, 3(5), 252. 
Matos, M. G., Santos, T., \& Reis, M. (2017). BePositive project: Positive Youth Development (PYD) in adolescents. Portuguese report. Saarbrucken: Lambert Academic Publishing.

Matos, M. G., Santos, T., Reis, M., \& Marques, A. (2018). Positive Youth Development: Interactions Between Healthy Lifestyle Behaviours and Psychosocial Variables. Global Journal of Health Science, 10(4), 68-76. https:// doi.org/10.5539/gjhs.v10n4p68

Matos, M. G., Tomé, G., Borges, A., Manso, D., Ferreira, P., \& Ferreira, A. (2008). Anxiety, Depression and Coping Strategies: Improving the evaluation and the understanding of these dimensions during pre-adolescence and adolescence. Journal of Cognitive and Behavioral Psychoterapies, 8(2), 169-184.

Nogueira, M. (2016). Saúde Mental em Estudantes do Ensino Superior: Factores Protectores e Fatores de Vunerabilidade. PhD Theses in Nursing (Unpublished). Escola Superior de Enfermagem de Lisboa da Universidade de Lisboa.

Reis, M., Gomez-Baya, D. Ramiro, L., \& Matos, M. G. (2020). Relationships between anxiety and aggression in a national sample of Portuguese youth: a moderated-mediation model of long-term and short-term self- regulation by internal. Journal of Education Research and Behavioral Sciences, 9(2). Retrieve from: http://www.apexjournal.org

Reis, M., Ramiro, L., Gomez-Baya, D., \& Matos. M.G. (2018). The promotion of healthy Universities: A systematic review. CPQ Women and Child Health, 1(3), 1-15.

Rose, A.J \& Rudolph, K.D (2006). A review of sex differences in peer relationship processes: Potential trade-offs for the emotional and behavioral development of girls and boys. Psychological Bulletin, 132, 98-131.

Scales, P., Roehlkepartain, E., \& Fraher, K. (2012). Do Developmental Assets Make a Difference in Majority-World Contexts? A Preliminary Study of the Relationships Between Developmental Assets and Selected International Development Priorities. Education Development Center, Inc. Search Institute.

Schleider, J. L., Abel, M. R., \& Weisz, J. R. (2015). Implicit theories and youth mental health problems: A random effects meta-analysis. Clinical Psychology Review, 35, 1-9. doi: 10.1016/j.cpr.2014.11.001

Small, S., \& Memmo, M. (2004). Contemporary Models of Youth Development and Problem Prevention: Toward an Integration of Terms, Concepts, and Models. Family Relations, 53, 3-11. doi: 10.1111/j.1741-3729.2004.00002.x

Simóes, C., Matos, M.G., \& Morgan, A. (2015). Facing the adversity: The role of internal assets on wellbeing in adolescents with special needs. Spanish Journal of Psychology, 18(e56), 1-14. doi: 10.1017/sjp.2015.41 
Silva, D. R, \& Spielberger, C. D. (2007). Manual do Inventário de Estado-Traço de Ansiedade (STAI). Consulting Psychologists Press, Inc..

Whitlock, J., \& Hamilton, S. (2001). Youth development principles and practices: Defining what it is and is not. Ithaca, NY: Unpublished manuscript, Department of Human Development, Cornell University.

Williams, A. S. (2013). Worry, intolerance of uncertainty, and statistics anxiety. Statistics Education Research Journal, 12, 48-59. [Online: www.stat.auckland. ac.nz/serj] 